DOI: https://doi.org/10.47405/mjssh.v5i10.537

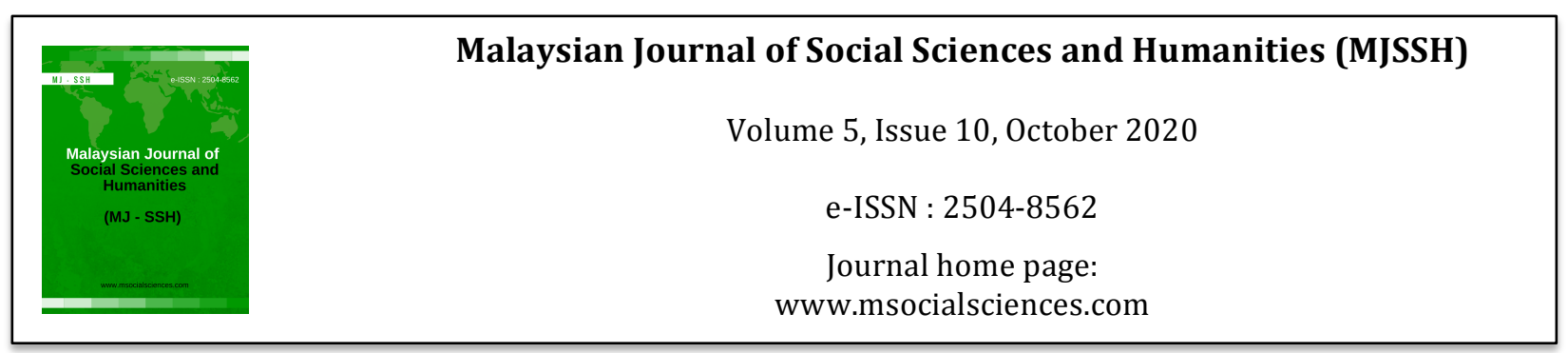

\title{
Customers' Satisfaction Towards 99Speedmart based on Product Quality and Service Quality in Bangsar, Kuala Lumpur
}

\author{
Nasrul Hakimi Bin Noor Azman'1, Ng Kah Xsin'1, Nur Sorfina Binti Suleiman', \\ Nur Iman An Nisaa Binti Nor Azman', Nor Azirah Binti Ayub ${ }^{1}$, \\ Nur Sabrina Binti Mohd Halid ${ }^{1}$, Nur Atiqah T.N Winda Wijaya ${ }^{1}$, Nur Adila Anati Binti Md Shah ${ }^{1}$, \\ Isai Amutan Krishnan ${ }^{2} \&$ Vasudevan Naidu Kanan ${ }^{3}$ \\ 1University of Malaya Centre for Continuing Education (UMCCed), Malaysia \\ 2Magic Palms School, Vientiane, Laos \\ ${ }^{30}$ 'Connor's Engineering Sdh Bhd, Malaysia
}

Correspondence: Isai Amutan Krishnan (amuthanisai@gmail.com)

\begin{abstract}
Convenience stores have been providing basic needs for their customers and have become one of the customer's pleasure to come to shop the essential needs for the household. This study focuses on the customer's satisfaction towards 99Speedmart by looking into two variables, which are Service Quality (SERVQUAL) and product quality. These two variables are vital to any business as it would affect its loyal customers if any of these did not meet their expectations. A survey was conducted by distributing the adapted questionnaire to 238 respondents that comprise three sections. The data was analysed quantitatively by using SPSS SPSS. It was found that many respondents showed positive results towards 99Speedmart which they are partly agreed that 99Speedmart provides good quality products and services.
\end{abstract}

Keywords: product quality, customers' satisfaction, service quality, convenience store

\section{Introduction}

In this contemporary era of our current generation nowadays, it is normal for a business to face a fluctuate performance, hence in order to sustain the growth of business in a long-term period and increasing the performance of the firm, consumers play a vital role in this context as they are the most crucial components to the firm. Any firm should take into account any complaints or reviews expressed by consumers regarding on the firm's performance. According to Russell-Bennett, McColl-Kennedy \& Coote (2007), customer satisfaction plays a significant role in shaping purchase intention in the future. Therefore, it is ought to the firm to provide an excellent service in ensuring the customers were satisfied with the service provided and quality of the goods purchased. Hence, there is a significant correlation between competitors and any other business as it is a nature in business area that we cannot avoid, thus, it is very vital to achieve loyal customers and repeat purchases that will induced to customer satisfaction (Sulek \& Hensley, 2004).

There are many issues regarding 99Speedmart's service and product quality that would affect customer satisfaction. One of the issues that 99Speedmart face in terms of service quality is insufficient staff. 99Speedmarts have limited staff compared to other convenience store where more staffs are available 
to assist customers. This causes customers' queries to be unattended and the items to be not replenished on the shelf. Moving on, 99Speedmart promised to provide friendly and helpful services to their customers. However, some customers complained that few staffs are rude, unhelpful and unfriendly. According to them, the staffs were even racist and insensitive towards the customers.

Furthermore, 99Speedmart only have 2 counters in every outlet. Sometimes during peak hours, customers have to wait in a long queue to check out. Moreover, the space inside the 99Speedmart store is limited. The limitation of space is due to poor inventory management. The inventories are situated near the shelf instead of being kept in the storeroom. As a matter of fact, the store will be crowded if there are many customers at one time and it will be inconvenient for customers to move around. Consequently, it creates an unpleasant shopping experience for their customers. The consciousness by Mmutle (2017, p.3) brings justification of "Failure to identify customer perceptions' may lead to poor efforts in services delivery and can be attributed to failure in the entire quality of service".

In terms of product quality, some products have defect due to poor arrangement in the storeroom. For instance, some food cans and drink cartons were dented. The foods and drinks contained in dented can and carton may be unsafe to consume as it has been contaminated.

As a result, it would impair the quality of the product and hence reducing customer satisfaction. This is because customers' satisfaction is influenced by product quality (Seyedi, Shirazifar, Dalvand, \& Zohdi, 2012). Therefore, it is important to ensure good product quality in order to improve customer satisfaction.

\section{Literature Review}

\section{Definition on the Customer Satisfaction}

According to Jeevananda (2011), customer satisfaction in simple terms defined as the level of purchasing experience in a retail outlet where the customer's expected service level is met with the actual service provided by the retailer. In business terms, it can be also explained as a measure of how products and services supplied by a company meet or surpass customer expectation. Aaker and Jacobson (1994), as cited in Ehsani (2015) said that product quality is the customer's perception of the overall quality or superiority of the product or service, with respect to its intended purpose, relative to alternatives. Meanwhile, Jones and Taylor (2007) stipulated that service loyalty is the degree to which a customer exhibits repeats purchasing behavior from service provider, possesses a positive attitudinal disposition toward the provider.

\section{Past Studies}

In a study conducted by Gronholdt, Martensen and Kristensen (2000) showed that customer loyalty is a function of customer satisfaction, and a loyal customer affects the company's finances performance. Seyedi et al. (2012) also stated that the product and service quality were the important factors affecting customer satisfaction. Moreover, the level of satisfaction depended on the extent to which the needs were met. A study conducted by Arokiasamy and Abdullah (2013) has reported that customer satisfaction is one of the most important issues concerning the business organisation of all types, which is justified by the customer-oriented philosophy and the principles of continues improvement in a modern enterprise. Wong and Zhou (2006), Aktepe, Ersöz and Toklu (2015) stated that satisfaction is one of the main factors that affects customer loyalty. These views are supported by Straker, Wrigley, and Rosemann (2015) who pointed that outstanding positive experience leads to affirmative behaviours in companies' and firms' activities making customers loyal to organisations' products and services.

According to Caruana (2002), service quality which act as an important gateway to customer satisfaction. Furthermore, Ryu, Han and Kim (2008) draws our attention to quality which identified as a main driver of satisfaction; and patrons' behavioural intention is a function of these variables. In the same vein, Cronin and Taylor (1992), Tsoukatos and Rand (2006), and Kim, Chang, Park and Lee 
(2004) service quality is linked to customer loyalty and satisfaction. This association has been ratified, and the study has proven the positive role of service quality towards customer satisfaction, which ultimately leads to customer loyalty (Santouridis \& Trivellas, 2010; Kuo, Wu \& Deng 2009; Turel \& Serenko, 2006; Kim et al., 2004).

In connection with product quality, Zamazalova (2008) mentioned that product (in terms of quality, availability); price (convenient payment method conditions); services; distribution and image of the product are the key factors that affect customer satisfaction. From the perspective of Razak, Nirwanto and Triatmanto (2016), if the perceived product quality is in line with the expectation, then the customer will perceive the product quality as good quality and also feel satisfied.

To conclude, these studies suggested that the quality of service and products do affect customer attitude and satisfaction with convenience stores. It is shown that there is a positive relationship between the customer's satisfaction, service quality and product quality as Sivadas and Baker-Prewitt (2000) ran a nationwide random phone survey of 542 buyers to check the relationship between services quality, customer satisfaction, and loyalty in the context of a retail store. Therefore, the current study will be focused on customer satisfaction that relying on the service and product quality in 99Speedmarts context.

\section{Methodology}

Figure 1 shows the conceptual framework outlines the correlation between customer satisfaction with product and service quality and intentions to switch. These two factors of customer perceptions which is product and service quality are independent variables and the dependent variable is customer satisfaction. In the present study, the relation between factors of these two independent variables and the customer satisfactions on product and service quality have been analyse through 99Speedmart's consumers.

Figure 1: The conceptual framework of factors influencing customers' satisfactions through product and service quality

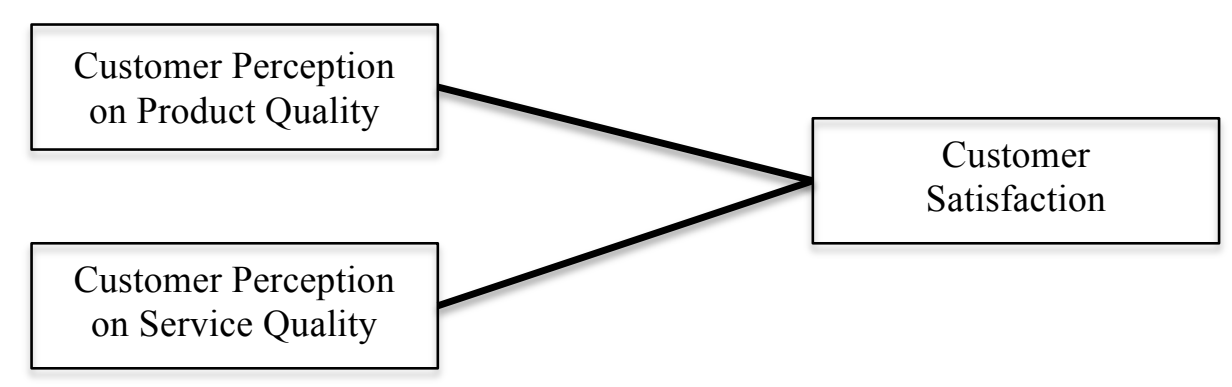

\section{Research Approach}

Figure 2 shows the overview of the research approach on setting, sampling and instrumentation. In order to ensure most of the respondents could read and understand, the questionnaire was designed in English. The organisation that has been chosen is 99Speedmart since few problems been discovered that has influenced the customer's satisfactions. Besides, the respondent was collected from the three different branches situated in Bangsar within the range 100 respondent comprise mixed raced and genders between $18-70$ years old. The questionnaire was divided into three sections; section A on demographic, section B and Section $\mathrm{C}$ on the service quality (SERVQUAL) and product quality by using 5-point Likert scale. Besides questionnaire, an interview was also conducted with the customers in order to get an exact point of view about 99Speedmart from them. 
Figure 2: Research approach on setting, sampling and instrumentation of the research

\begin{tabular}{|c|}
\hline SETTING \\
Organization: \\
99Speedmart \\
Nature of Business: \\
A Convenience Stores \\
Location: \\
Bangsar \\
\end{tabular}

\begin{tabular}{|c|}
\hline SAMPLING \\
Number of \\
Participants: \\
100 \\
Age: \\
$18-70$ \\
Gender: \\
Male and Female \\
Race: \\
Mixed Races \\
\hline
\end{tabular}

\section{INSTRUMENTATION}

Interview

Questionnaire

Evaluation Form

INSTRUMENTS

Previous Studies

Survey Questionnaire

Comprise of 3 Sections

Service and Product

Quality

\section{Data Collection and Data Analysis Procedures}

Figures 3 shows the data collection and analysis procedures. The steps are explained accordingly. It is crucial to have an ethical clearance to conduct this study since it involves human participants and their data. A consent should be obtained to ensure that no one is harmed or suffered by adverse consequences while any stage of the research is conducted. Therefore, an approval letter has been obtained from UMCCed's management to conduct the study. The second step is sampling and data collection. The data was collected from the completed versions of the questionnaire. The respondents were 99Speedmart's customers in Bangsar, Kuala Lumpur and the age ranges were 18 to 70 . The third step is adapting the questionnaire. The questionnaire was developed based on the Likert Scale which is a type of measurement that allows the respondent to express the level of agreement or disagreement with a particular statement. The questionnaire has been adapted from Aspfors (2010) previous study. A pilot test was conducted using the questionnaire in a sample of 10 respondents among 99Speedmart's customers in Bangsar, Kuala Lumpur to ensure that the instrument is reliable and valid. Finally, the data are analysed and interpreted. The findings are discussed in detail too.

Figure 3: Data collection Analysis Procedures

\begin{tabular}{|c|c|}
\hline Step 1 : Consent & $\begin{array}{l}\text {-The researcher collected written approval letter from UMCCED's } \\
\text { management to conduct the study. }\end{array}$ \\
\hline $\begin{array}{l}\text { Step } 2 \text { : Sampling and } \\
\text { Data Collection }\end{array}$ & - The data colleted from the completed versions of questionnaire \\
\hline $\begin{array}{l}\text { Step 3: Adapting } \\
\text { Questionnaire }\end{array}$ & $\begin{array}{l}\text {-Pilot testing } \\
\text {-Questionnaire (10 respondent) }\end{array}$ \\
\hline Step 4: Analysing Data & $\begin{array}{l}\text { - Close ended mode of strutured questionnaire and structured interview } \\
\text { have been used and conducted to analyze the collected data }\end{array}$ \\
\hline $\begin{array}{l}\text { Step 5: Interpretation of } \\
\text { Results }\end{array}$ & -The findings have been discussed in details \\
\hline
\end{tabular}




\section{Reliability and Validity}

Based on the Tables 1 and 2, the result shows that the reliability statistics for the pilot study based on Cronbach's Alpha is 0.867 and 0.878 for product quality and service quality respectively. Consequently, when the Cronbach Alpha esteem exceed 0.7, accumulation of finished information for whatever is left of the example respondents must be presently done before conducting further analysis. Since the esteem here are above 0.8 , hence it is more prominent than 0.7 and below 1 . Therefore, it is enough to represent that the information is solid and the model is reliable for further analysis.

Table 1: Product Quality Alpha Value

\begin{tabular}{ll}
\hline Reliability Statistics & \\
\hline Cronbach's Alpha & No of Items \\
.867 & 11 \\
\hline
\end{tabular}

Table 2: Service Quality Alpha Value

\begin{tabular}{cc}
\hline \multicolumn{2}{c}{ Reliability Statistics } \\
\hline Cronbach's Alpha & No of Items \\
\hline .878 & 15 \\
\hline
\end{tabular}

\section{Analysis and Discussion}

The data has been collected from 238 respondents by utilizing the sample size determination table of Krejcie and Morgan (1970). A sample size of 234 is needed to represent a cross-section of the total 600 daily customers of three branches in Bangsar. An additional four questionnaires are distributed to avoid from any unused or blank responses. The targeted respondents of this questionnaire are the customers of 99Speedmart. The questionnaires consisted altogether of 26 questions divided into three different sections. Section A is demographic information of respondents such as age, gender and the frequency of respondents visited to 99Speedmart. Section B and C consist of 11 questions each about the product quality and service quality of 99Speedmart. A comparison question between 99Speedmart's service and other similar stores will be included in Section C. The statements of questionnaire are to determine the factors that affect customers' satisfaction towards 99Speedmart. In the last section, the respondents also had the opportunity to pick "I don't know" option as this is added to avoid if the respondents do not visit any other stores before.

\section{Section A: Demographic Information}

Figure 4 shows the percentage of respondents who have filled out the questionnaire in six age categories. There are 80 respondents (34\%) that are in the range of 21 to 30 years old, 51 respondents $(21 \%)$ are in the range of 20 years old and below, 46 respondents (19\%) are in the range of 31 to 40 years old. In the range of 41 to 50 years old, the result shows the percentage of $14 \%$ which in the amount of 34 respondents while 51 to 60 years old and above shows 16 respondents (7\%) and 11 respondents $(5 \%)$ respectively. From the chart, it reveals that the greatest demand of customers in Bangsar are aged between 21 to 30 years old. 
Figure 4: Age of respondents

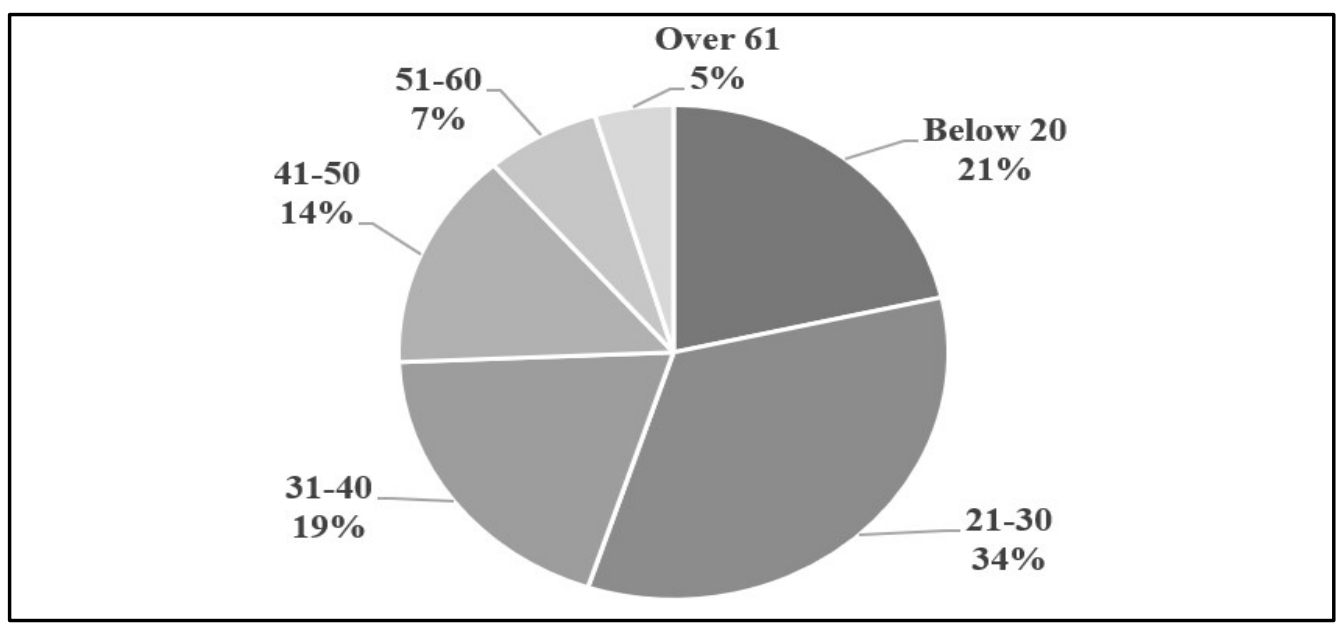

Figure 5 shows the percentage of respondents who answered the questionnaire based on their gender. Overall, the females have a significantly higher rate than males. As can be seen, the result indicated that the questionnaire has 238 respondents in total. Therefore, there are 100 male respondents have filled in the questionnaire, which shows the percentage of $42 \%$ while there are 138 respondents are female and shows the percentage of $58 \%$. Hence, the total respondents are equivalent to 100 per cent. There is a clear trend showing that female has remained higher than male to make grocery purchase.

Figure 5: Gender of respondents

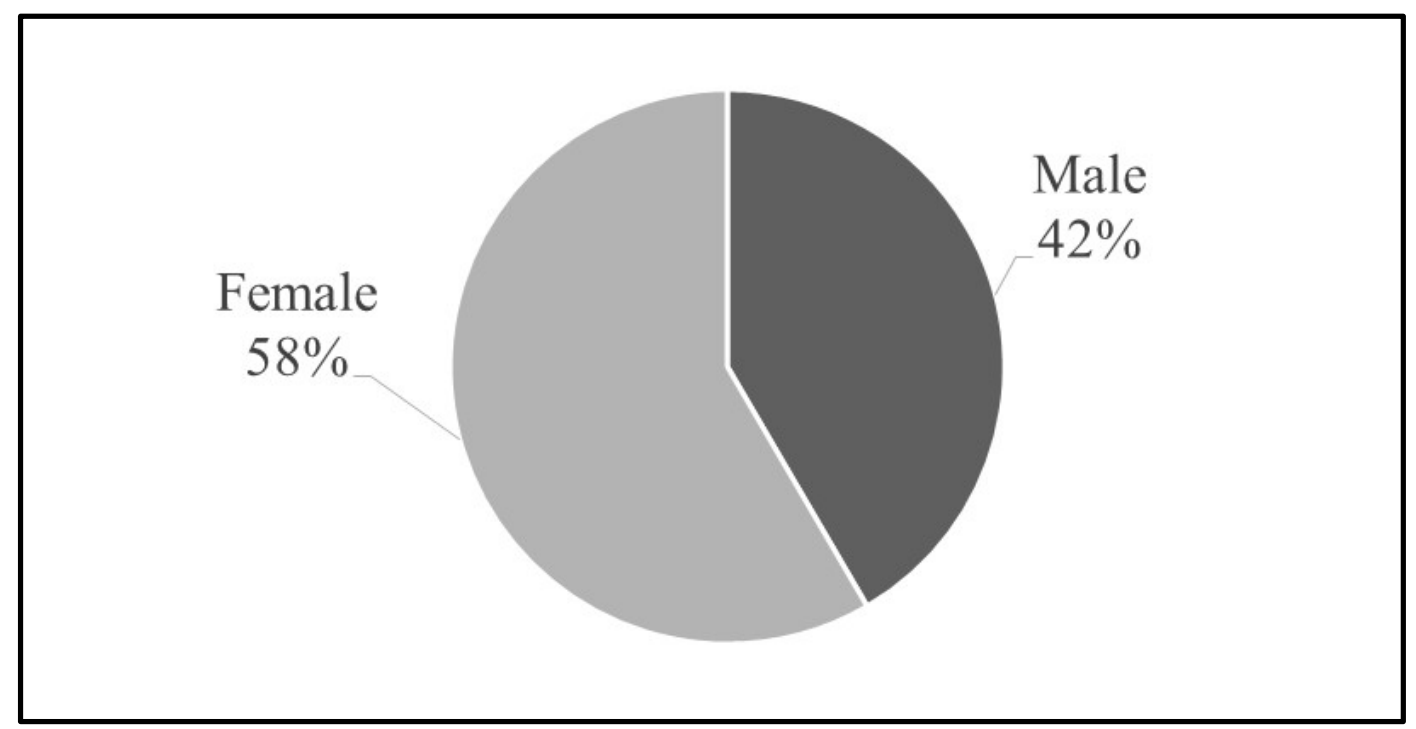

Figure 6 shows the frequency of the respondents visited to 99Speedmart. The highest percentage goes to once a week (30\%) and the lowest percentage goes to almost daily $(6 \%)$ respectively. Most of the respondents tend to visit 99 Speedmart once a week but they did not prefer to go almost daily due to inconvenience. As much as $24 \%$ of respondents preferred twice a month. The result indicated that some respondents were making their grocery shopping in 99Speedmart once a month $(21 \%)$ or only a few times in a year (19\%). 
Figure 6: The frequency of respondents visited to 99Speedmart

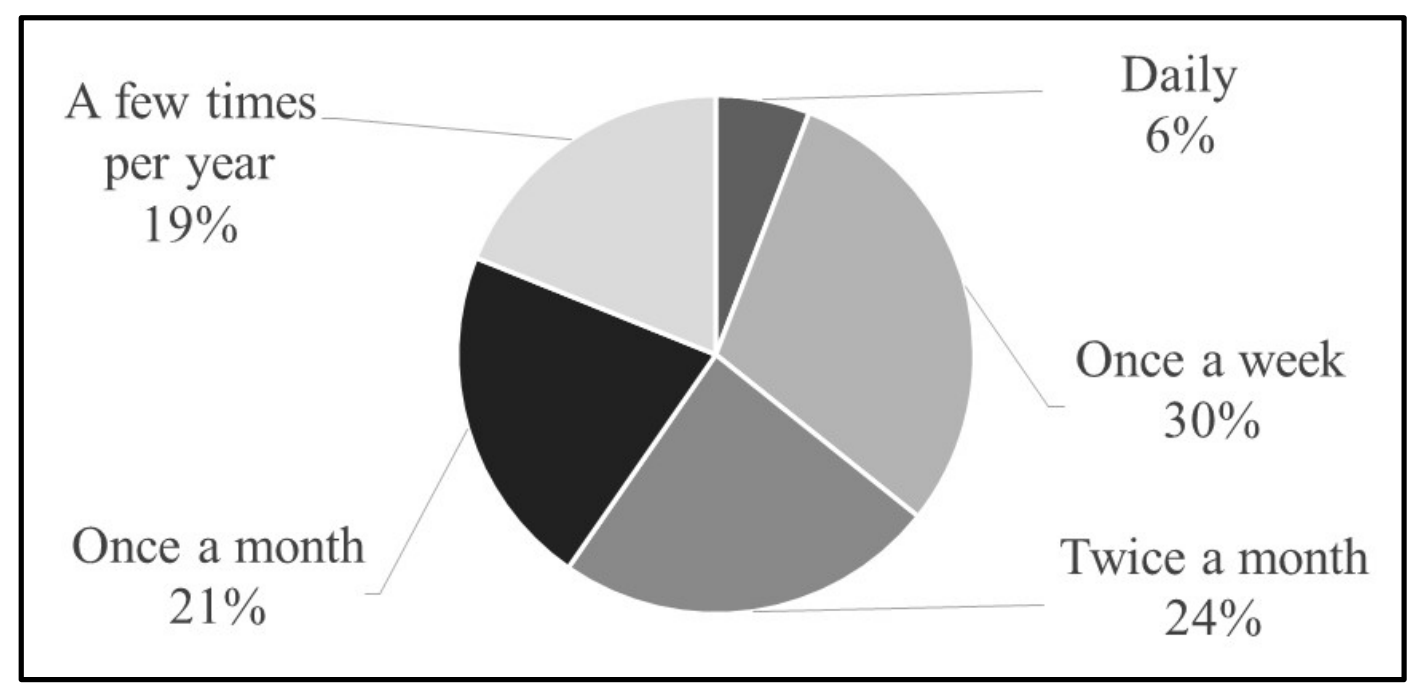

\section{Section B: Product Quality}

Section B and C in the questionnaire consisted of Likert-Scale Questions regarding the product quality and service quality of 99Speedmart. The respondents were asked to take position whether or otherwise they considered the statements agreement on a scale from one to five. One corresponded to "Disagree" and five to "Agree". These statements were asked in order to find out if there were any gaps between the respondents' general opinions about product quality and service quality of 99 Speedmart. In Section $\mathrm{C}$, the respondents are required to compare the service they receive from other similar stores. The "I don't know" option is added in case there are respondents who had never experienced of another similar store. Overall, the respondents found most of the statements to be "Partly Agree" or "Neutral".

Figure 7 shows that 103 respondents who partly agreeing that the products of 99Speedment are of high quality. It shows a significant number of respondents (109 people) who partly agreed the statement of "the product range meet your expectations". Among the 238 respondents, there are only three of the respondents disagree the products are enough to choose from. The number of respondents who selected "Partly Agree" and "Neutral" regarding the sufficiency of product line are equal in a total of 80 respectively. Overall, the customers of 99Speedmart are partly satisfied or agreed with the products range and quality as it fulfilled their expectations. The amount of disagreement in each statement is below than 10 respondents. It means the product quality of 99Speedmart is still in an acceptable range by the customers.

Figure 7: Likert scale questions regarding 99Speedmart's product quality from Question A to D.

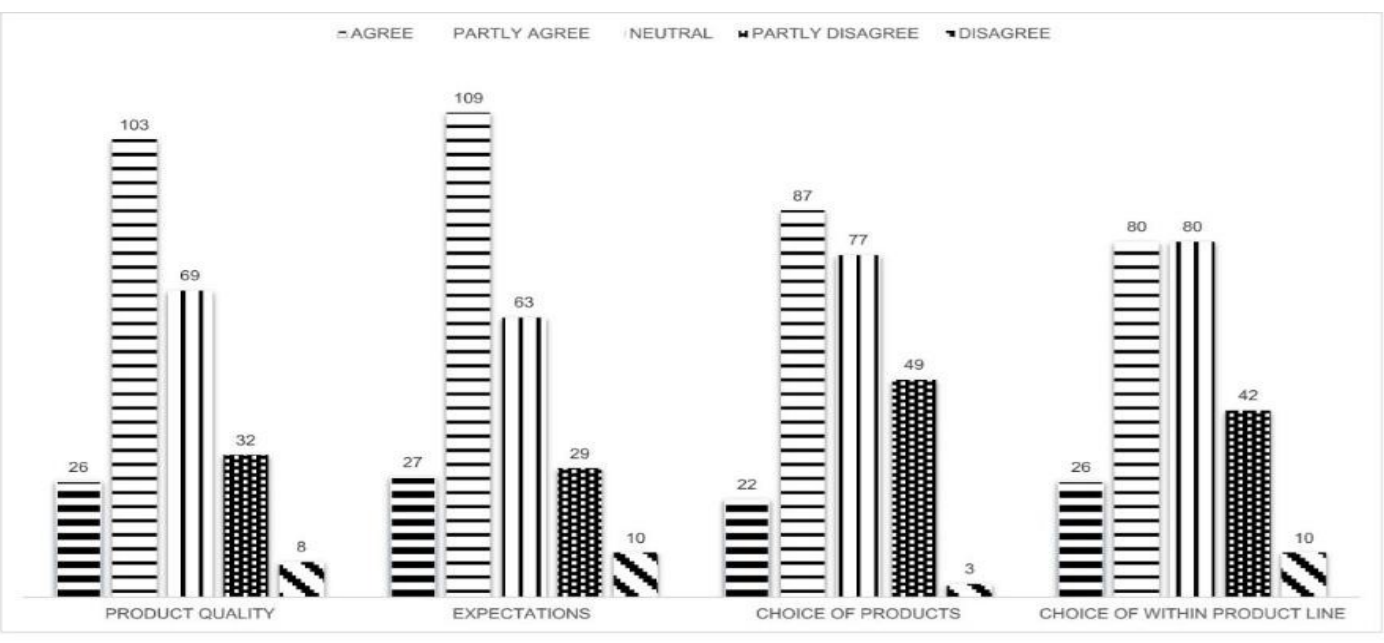


Figure 8 shows that most of the respondents are partly agree that the products are always provided in good condition. At the same time, there are 101 and 102 of respondents neither agreed nor disagreed with the statements of "the products are fresh" and "the products have that extra something". However, the respondents who had an opinion of partly agree in the statement of "the products are fresh" shows the second highest among the four questions in the number of 81 respondents while there are only four respondents picked the "Disagree" option in that statement. Generally, the condition of product is one of the key factors that can influence the customer satisfaction of 99Speedmart.

Figure 8: Likert scale questions regarding 99Speedmart's product quality from Question E to H

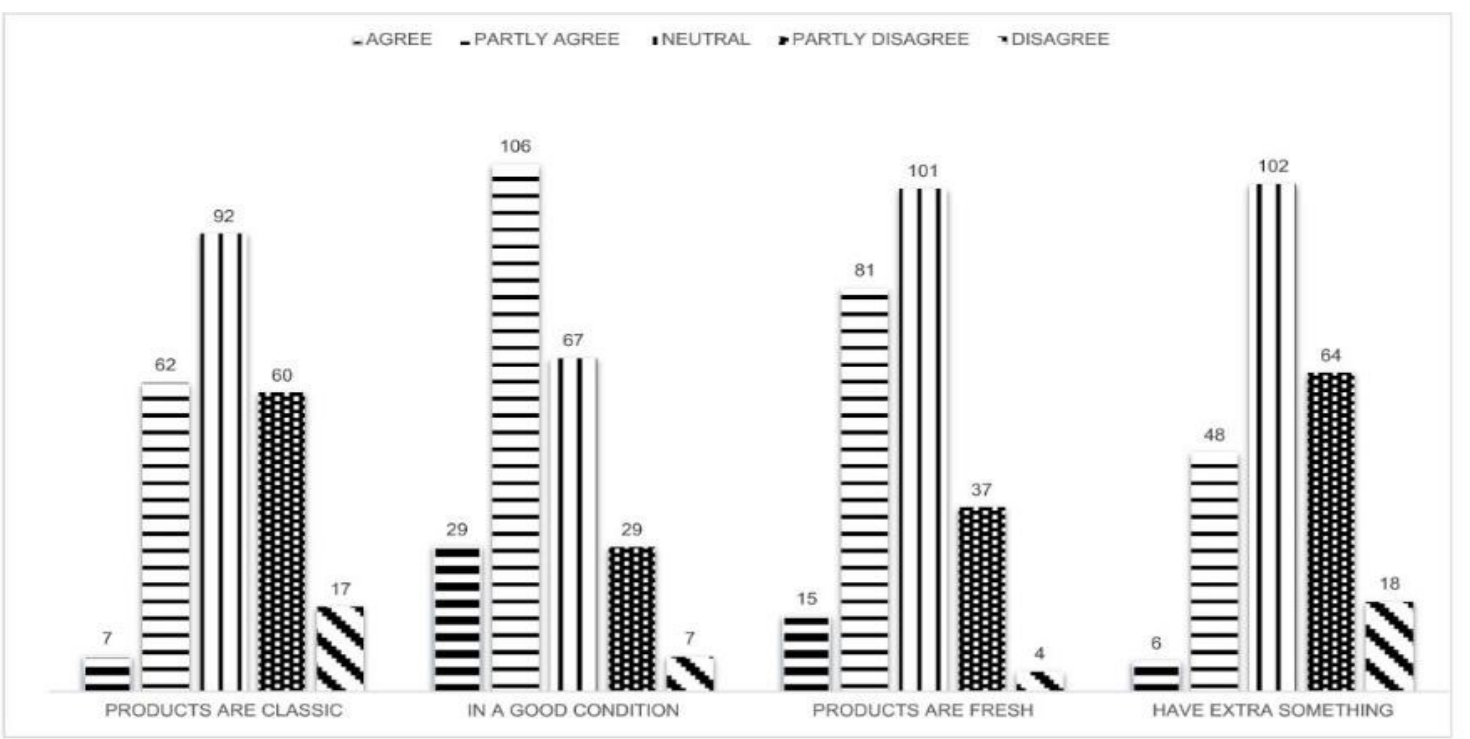

Figure 9 shows the majority of the customers are satisfied with the products offered by 99Speedmart. There are 112 of respondents considered this statement to be "Partly Agree". Moreover, as much as 100 respondents are partly agree that the products they bought are worth the money and 73 respondents picked "Agreed". However, the statement that scored high rate in "Disagree" and "Partly Disagree" options are the frequency of products presented. The result shows that 46 respondents are partly disagreed with the products in 99Speedmart are frequently presented and 18 respondents selected "Disagree" in this statement. Overall, 99Speedmart has received average responses toward the product quality from customers.

Figure 9: Likert scale questions regarding 99Speedmart's product quality from Question I to K.

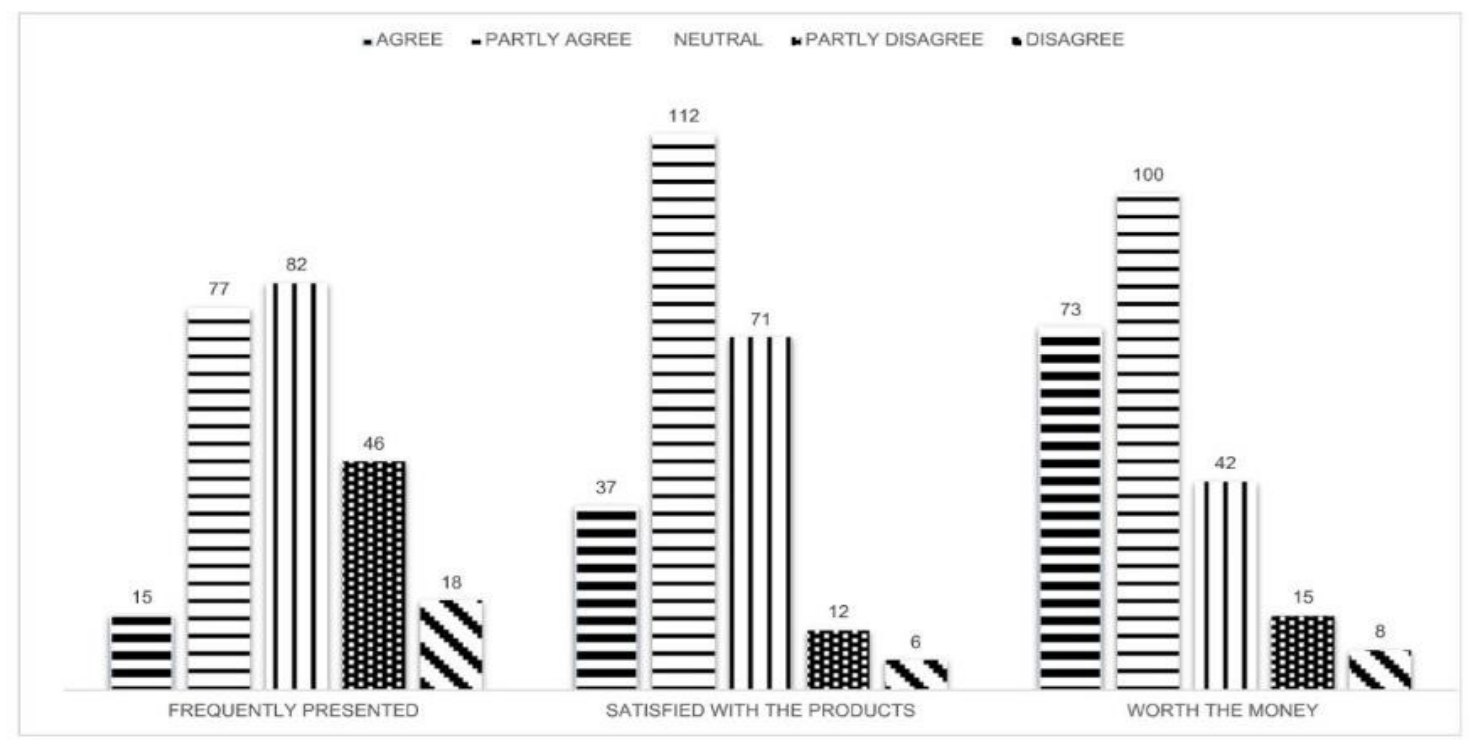


Figure 10 shows that are 98 out of 238 respondents partly agree with the statement of "you receive good service" and 22 out of 238 respondents chose to agree with this statement. The personnel are friendly, and professional have received 81 responses which are partly agree in this section. While "the interior is appealing" is reported neither agreed nor disagreed with 93 respondents. However, 59 of respondents claim partly disagreed because the interior is not appealing at all. There are only seven respondents disagree with the statement "the service provided is good" and seven respondents agreed with the "interior designed is appealing". What stands out in this table is the customers are mostly received a good service from the personnel.

Figure 10: Likert scale questions regarding 99Speedmart's service quality from Question A to D

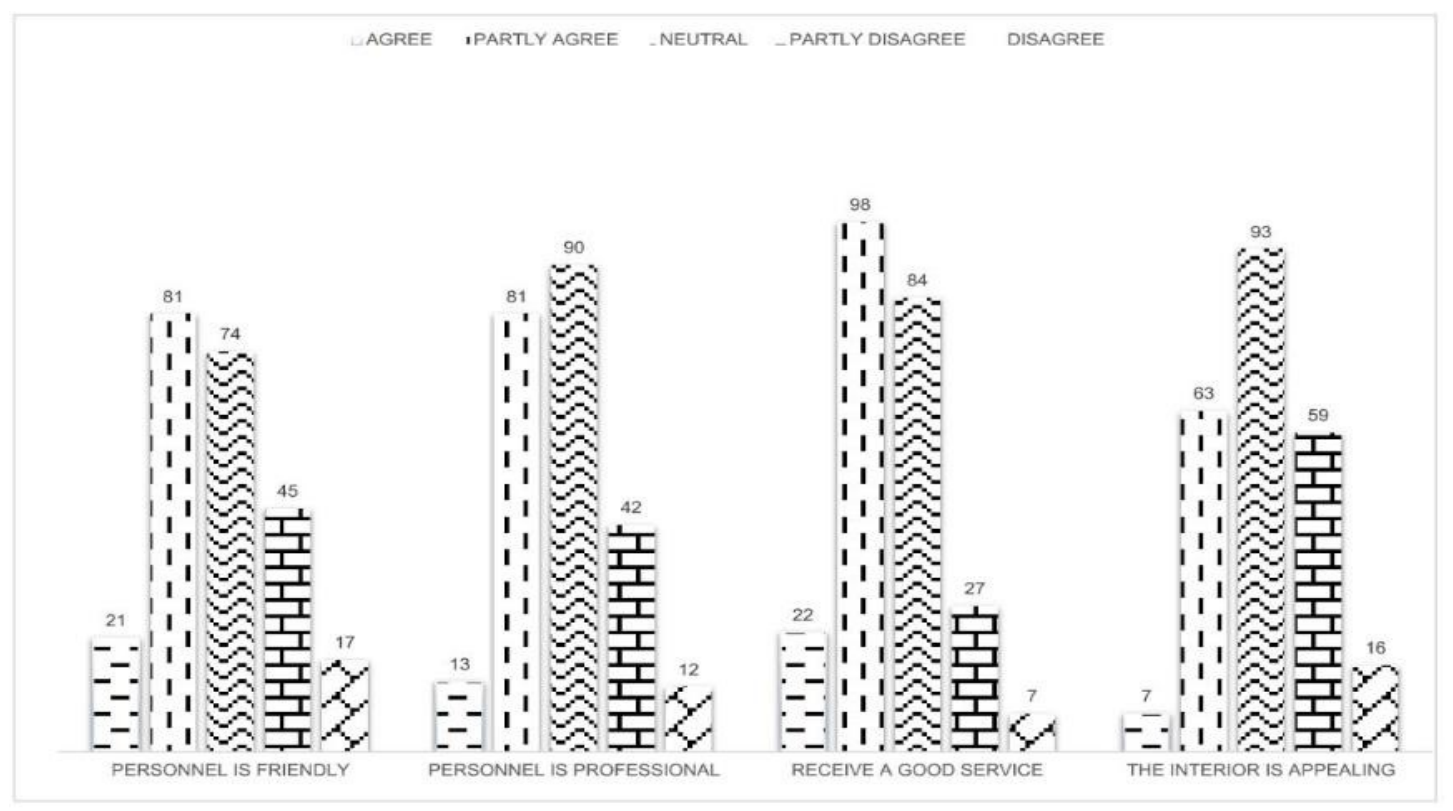

Figure 11 shows that the highest rate of neutral as 102 of respondents picked "Neither Agreed nor Disagree" option. It can be said that 99Speedmart is still taking initiative to offer plastic bags for their customers in 20 sens each during checkout process. The respondents who partly agree the image of store is and the prices are advantageous have almost reached the same result severally, which is 86 and 87 respondents. As much as 53 respondents realized that the prices in 99Speedmart are advantageous. However, there are 63 and 60 of respondents found it difficult or even impossible to have the possibility to spend time with customer and personnel due to the limitation of space. Interestingly, the environmental consciousness of 99Speedmart is required to be strengthened in order to increase the awareness of customers and its service quality.

Figure 11: Likert scale questions regarding 99Speedmart's service quality from Question E to $\mathrm{H}$

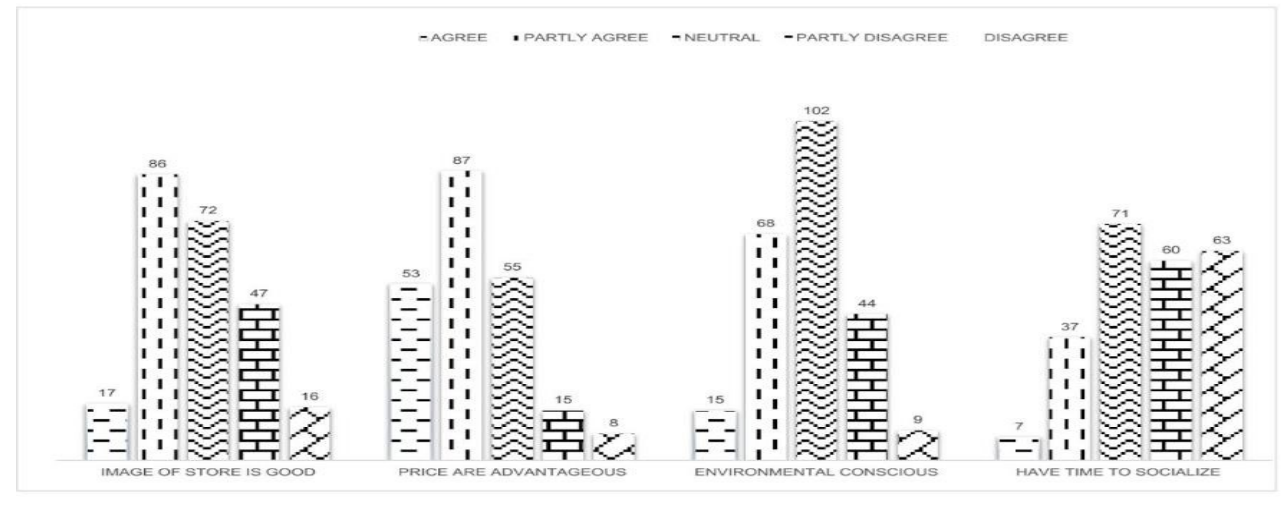

Figure 12 shows that the statement that is considered "Disagree" among a half of the respondents is "possibilities to sit down and drink" which reported by 112 of the respondents because 99Speedmart 
tends to be a grocery shopping store. Besides that, "the store has good parking possibilities" scored high rate in "Neutral" which has received 76 responses from 99Speedmart customers. Only six of the respondents who agree that 99Speedmart's parking spaces are sufficiency, it is easier to find the parking spaces during weekdays as compared to weekend. There are 63 and almost 70 of respondents are partly agreed that the store has offered a good, extra services. In contrast, there are 35 respondents disagreed with this statement. Overall, the service quality of 99Speedmart has achieved an average level as to compare with other similar stores.

Figure 12: Likert scale questions regarding 99Speedmart's service quality from Question I to K

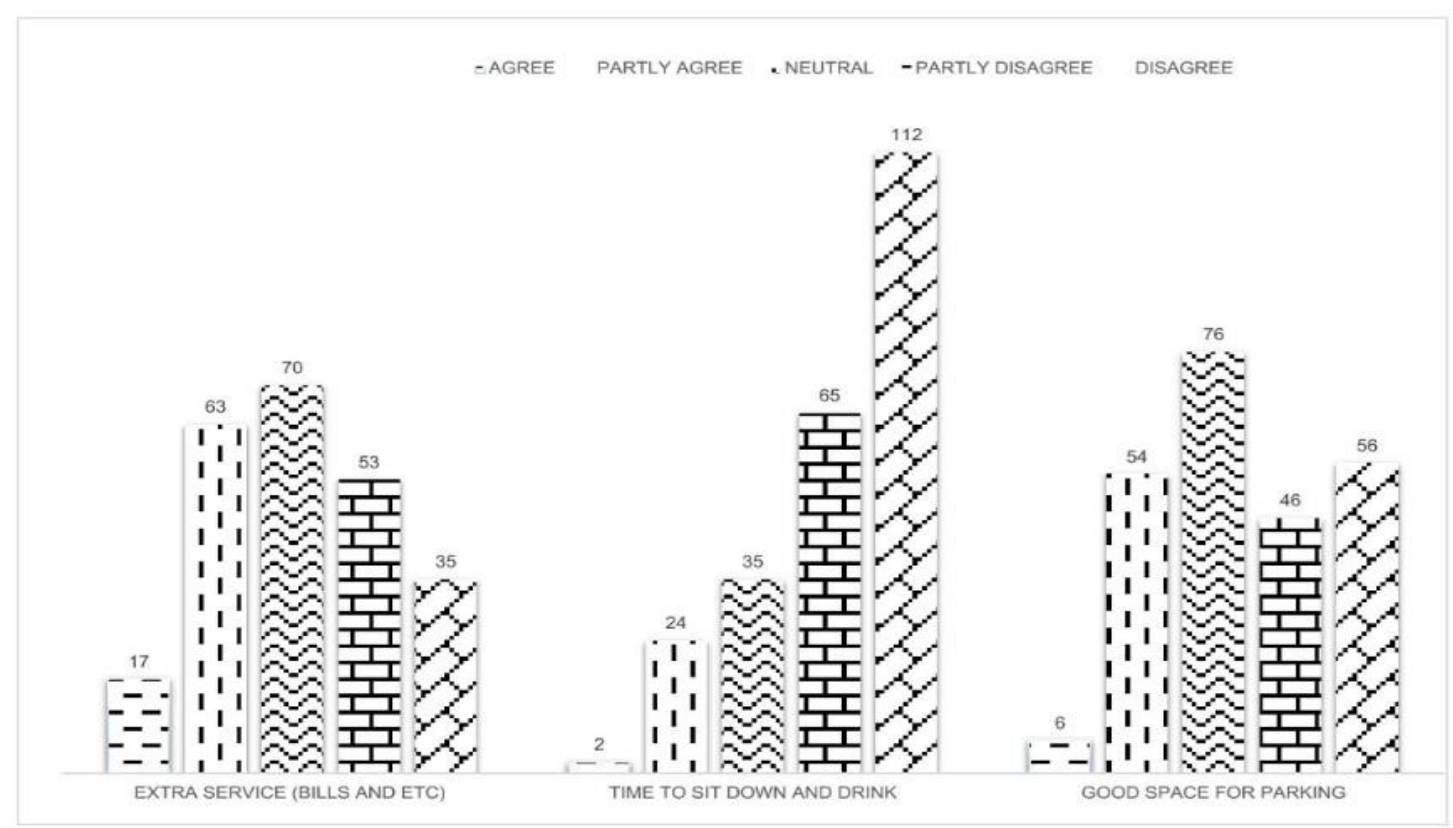

Figure 13 shows that 99 Speedmart is more deemed as somewhat the same. The result is evaluated by 95 respondents as they do not recognise any dominance of 99Speedmart that can maintain their loyalties towards the brands. However, there are 85 of the respondents considered that 99 Speedmart is better than other stores. "A lot better" goes to the third place, where 32 respondents with $13 \%$ agreed that 99Speedmart is a lot better compared to its rivals. There are 16 respondents with $7 \%$ chose that 99Speedmart is worse in its service quality and the rest 10 respondents did not know the difference between 99Speedmart and other convenience stores. It is worth mentioning that no respondent from 99Speedmart picked "A lot worse" option in this ranking. Overall, it can be said that the service quality of 99Speedmart has a lot of space remains for improvement and future work.

Figure 13: The comparison between the service quality of 99Speedmart and other similar stores

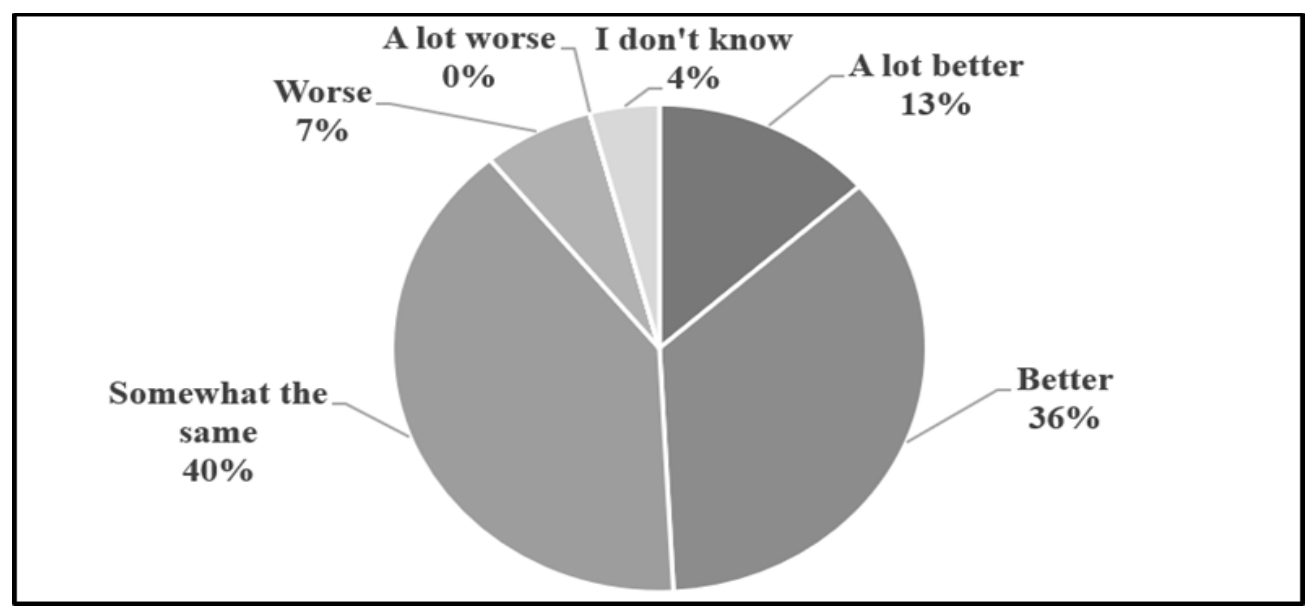




\section{Discussion}

The findings revealed a positive result, customer's expectation of product quality and features are met as well as the service quality of 99Speedmart are good. Nevertheless, this study helps the company to discover and learn in-depth regarding their customers' opinion and perception. Thus, they would be equipped with the knowledge on how to serve their customers better in future.

For the demographic section, the result shows the high percentage of the age is from 21 to 30 years old and most of them are female. This could be justified as women are the one often responsible for grocery shopping. As a matter of fact, groceries are the daily necessities required for every household. Based on the results of our study, the high percentage of respondents who often visit 99Speedmart is at least once a week.

Next section is about the product quality of 99Speedmart. The result implies that most of the respondents partly agree that product served by 99 Speedmart meet the expectation, have various choices, in good condition and fresh. All this term is identified as factors affecting customer's satisfaction on product quality of 99Speedmart. The result shows a positive answer and they are partly satisfied with the products of 99Speedmart. Moreover, the last section of the questionnaire discusses on service quality of 99 speedmart. One of the reasons why we conducted this research is due to a significant number of complaints regarding the personnel's attitude. Meanwhile, the result shows that all respondents partly that personnel of 99Speedmart are friendly and professional. In terms of the interior of the 99Speedmart, they partly agree that have a good interior. 99Speedmart is a store that sells groceries, so their store area is quite limited and customers do not have time to socialize with others. For the parking space provided by 99 Speedmart, the result show most of the respondent answered neutral. Parking space for a store depends on the location itself. The density of a resident in a given area will cause the parking space to be a little harder to find. In conclusion, as compared to the other convenience stores, 99Speedmart is more deemed as somewhat the same. This shows they are partly satisfied with the product and service quality of 99Speedmart. To conclude, we refer back to the research questions. Whether the research answers our questions or not. There is two research question in the study. Firstly, whether product and service quality affect customer satisfaction of 99Speedmart. The answer is yes. Under product quality, 99Speedmart need to make sure all the product meets the expectations, served in good condition, fresh and have a variety choice in term of product line. Meanwhile, for service quality, 99Speedmart should train their personnel and ensure the personnel possess good attitude. Personnel attitude is prominent to provide a good service. The interior of the shop and the size of the shop space should also be taken care of. Next question is the challenges facing by 99 speedmart currently. After doing all the analysis, it is proven that 99 Speedmart has problems with shop space and limited parking space. Hence, 99Speedmart need to implement some improvement in order to give a best service quality.

The purpose of this research was to identify the customer's satisfaction towards 99speedmart. The objectives were two folded, to measure the effectiveness of 99speedmart customers' service and product quality. This research also reviews all factors that influenced the customer's satisfactions towards 99speedmart and will be emphasize more in term of service quality (SERVQUAL) and product quality that were all combined as one and formulated a customer's satisfaction.

It was found that product quality has an influence on customers' satisfaction. A survey for this research was conducted by distributing a questionnaire to 238 respondents that comprise with three sections. The questionnaire was adapted from past study, an article from Aspfors (2010). However, a few questions were added according to 99speedmart context and was analysed through SPSS. Additionally, the Cronbach's alpha value shows that the questionnaire was reliable with the value of 0.867 for the product quality questions and 0.878 for the service quality questions.

As a result, many respondents show a positive result towards 99Speedmart which they are partly agreed that 99 speedmart does provide a good quality product and service and most respondents that went to 99 speedmart comes from the range age of 21 to 30 years old. Based on the data collected, $42 \%$ of respondent stated that 99 Speedmart is somewhat the same comparing to other stores. $100 \%$ of the 
respondent have visited 99Speedmart, the only differences are the oftenest. This research also gives a clear picture and provide an insight to 99Speedmart regarding on their customers' demands, needs and wants.

\section{Implication of the Study}

This study is conducted to examine the factors that influence the customers' satisfaction towards 99Speedmart. The findings provide helpful information about the factors influencing customers' satisfaction to 99Speedmart and the company to understand the customers' needs and wants. The implications of the study are described as follows.

According to Senthilkumar (2012), the quality of the product can improve customer satisfaction thus making them purchase the products. This would then lead to word-of-mouth. It was found that the customers of 99Speedmart were satisfied with the quality of the products. However, the management needs to continuously improve and provide high quality product to customers to ensure that the customers are fully satisfied with quality of the product especially in this competitive business. Proper quality checking process needs to be done to ensure that the products have no defects when receiving the products from the suppliers and before placing the products on the shelf.

Service quality is one of the essential elements in influencing customers' satisfaction (Weerasiri, 2015). It has been found that 99Speedmart's service quality is in an average level compared to its competitors. This shows that 99Speedmart's service quality needs improvement in order to stay ahead of the competition as good service quality leads to higher customers' satisfaction. The management of 99Speedmart should implement a good reward system or compensation package in order to motivate the employees. As a result, it will motivate them to provide high-quality service to the customers.

\section{Limitations of the Study}

There are some limitations that can be found in this research study which could be addressed in future research even though this research study has been completed successfully.

The first limitation of this research is the respondents' cooperation. This was because many respondents were rushing after buying goods in the store. Hence, the respondents might not answer the questionnaires with much considerations and they might not understand the questions. There are even many incomplete responses from the respondents and the responses were discarded from the research study. This shows that some respondents did not answer the survey with their true opinion and view but only to complete the survey. Hence, it could impact the accuracy of the findings.

Secondly, the survey questionnaires were only conducted in English Language and there might be a probability that some of the respondents might not understand the questionnaires well respondents but refuse to ask the researchers for clarification in order to provide accurate answer. The respondents might also misunderstand the questions although the questionnaires are written in simple and straightforward English sentences. Thus, the result may be incomplete or untrustworthy.

Thirdly, there was a boundary restriction in terms of geographical area and focuses solely on Bangsar, Kuala Lumpur. The data collected was limited to only some branches of 99Speedmart in Bangsar, Kuala Lumpur and the results cannot be used to represent all 99Speedmart stores in Malaysia. Therefore, the result might be biased and inaccurate because other states were not included.

\section{Conclusion}

The finding has shown a positive sign where most of the respondents are partly satisfied with 99Speedmart product and service. Thus, by conducting this study it could provide an insight to 
99Speedmart regarding on the customers' demands, needs and wants. The company itself could review all the factors contributing to the dissatisfaction of customers, for instance any defects occur in a product will affect the purchase intention. This is because according to Mittal and Kamakura (2001) that customer loyalty as essentially behavioral intention includes repurchase intention, positive wordof-mouth, marketing and willingness to pay more. Therefore, it is crucial for 99Speedmart to take any complaints into consideration to improve and enhance their business operation. As the study was based on customers' satisfaction toward 99Speedmart focus on the city area that has been highlighted on its products and service quality. A further study can be conducted in the rural area as to expand the data analysis by providing better quality and services throughout the country.

\section{References}

Aktepe, A., Ersöz, S., \& Toklu, B. (2015). Customer satisfaction and loyalty analysis with classification algorithms and Structural Equation Modeling. Computers \& Industrial Engineering, 86, 95-106.

Arokiasamy, A. R. A., \& Abdullah, A. G. (2013). Service quality and customer satisfaction in the cellular telecommunication service provider in Malaysia. Researchers World, 4(2).

Aspfors, E. (2010). Customer perception of service, store image and product assortment: from an interior store perspective (Published Thesis). Retrieved on 16 April, 2019, from https://core.ac.uk/download/pdf/38011045.pdf

Caruana, A. (2002). Service loyalty: The effects of service quality and the mediatin role of customer satisfaction. European Journal of Marketing, 36(7/8), 811-828.

Cronin, J.J., Jr. and Taylor, S.A. (1992) 'Measuring service quality: a re-examination and extension', Journal of Marketing, 56(3), 55-68.

Kuo, Y.F., Wu, C.M. \& Deng, W.J. (2009). The relationships among service quality, perceived value, customer satisfaction, and post-purchase intention in mobile value-added services. Computers in human behavior, 25(4), 887-896.

Ehsani, Z., \& Ehsani, M. H. (2015). Effect of quality and price on customer satisfaction and commitment in Iran auto industry. International Journal of Service Science, Management and Engineering, 1(5), 53.

Gronholdt, L., Martensen, A., \& Kristensen, K. (2000). The relationship between customer satisfaction and loyalty: cross-industry differences. Total Quality Management, 11(4-6), 509-514.

Hsieh, S., Lu, C., \& Lu, Y. (2018). A study on the relationship among brand image, service quality, customer satisfaction, and customer loyalty - Taking 'the Bao Wei Zhen Catering Team' As an Empirical Study. KnE Social Sciences, 3(10). doi:10.18502/kss.v3i10.3512

Jeevananda, S. (2011). A study on customer satisfaction level at hypermarkets in Indian retail industry. Research Journal of Social Science \& Management, 1(3), 2.

Jones, T., \& Taylor, S. F. (2007). The conceptual domain of service loyalty: how many dimensions?. Journal of Services Marketing, 21(1), 36-51.

Kim, M., Chang, Y., Park, M. C., \& Lee, J. (2015). The effect of quality on the satisfaction and the loyalty of Smartphone users. Telematics and Informatics, 32(4), 949-960. http://dx.doi.org/10.1016/j.tele.2015.05.003.

Kim, M. K., Park, M. C., \& Jeong, D. H. (2004). The effects of customer satisfaction and switching barrier on customer loyalty in Korean mobile telecommunication services. Telecommunications policy, 28(2), 145-159.

Krejcie, R. V., \& Morgan, D. W. (1970). Determining sample size for research activities. Educational and psychological measurement, 30(3), 607-610.

Mansour, R. (2018). A study on consumer satisfaction of supermarket in Mysore City, Mysore. International Journal of Research in Business Studies and Management, 5(5), 23-29.

Mittal, V., \& Kamakura, W. A. (2001). Satisfaction, repurchase intent, and repurchase behavior: Investigating the moderating effect of customer characteristics. Journal of marketing research, 38(1), 131-142.

Mmutle, T. (2017). Customers' perception of service quality and its impact on reputation in the hospitality industry. African Journal of Hospitality, Tourism and Leisure, 6(3), 1-25. 
Rizvi, D. A., \& Sabir, D. A. (2018). The relationship between customer satisfaction and service quality with special reference to the hypermarkets in Saudi Arabia. Research In Economics and Management, 3(3), 160. doi:10.22158/rem.v3n3p160

Russell-Bennett, R., McColl-Kennedy, J. R., \& Coote, L. V. (2007). Involvement, satisfaction, and brand loyalty in a small business services setting. Journal of Business Research, 60(12), 12531260 .

Ryu, K., Han, H., \& Kim, T. (2008). The relationships among overall quick-casual restaurant image, perceived value, customer satisfaction, and behavioral intentions. International Journal of Hospitality Management, 27(3), 459-469. doi: 10.1016/j.jhm.2007.11.001

Santouridis, I., \& Trivellas, P. (2010). Investigating the impact of service quality and customer satisfaction on customer loyalty in mobile telephony in Greece. The TQM Journal.

Saravanan, R., \& Rao, K. S. P. (2007). Measurement of service quality from the customer's perspective-an empirical study. Total Quality Management and Business Excellence, 18(4), 435-449.

Senthilkumar, V. (2012). A study on the effects of customer service and product quality on customer satisfaction and loyalty. Namex International Journal of Management Research, 2(2), 123-129.

Seyedi, S. M., Shirazifar, M., Dalv, M. R., \& Zohdi, M. H. (2012). Optimal examination and prioritization of the factors affecting customers' satisfaction using integrated Quality Function Deployment (QFD) and Kanos model: Case study of Shirazs Refah bank. African Journal of Business Management, 6(35), 9762-9772.

Sivadas, E., \& Baker Prewitt, J. L. (2000). An examination of the relationship between service quality, customer satisfaction, and store loyalty. International Journal of Retail \& Distribution Management.

Straker, K., Wrigley, C., \& Rosemann, M. (2015). The role of design in the future of digital channels: Conceptual insights and future research directions. Journal of Retailing and Consumer Services, $26,133-140$.

Sulek, J. M., \& Hensley, R. L. (2004). The relative importance of food, atmosphere, and fairness of wait: The case of a full-service restaurant. Cornell Hotel and Restaurant Administration Quarterly, 45(3), 235-247.

Tabaku, E., \& Kushi, E. (2013). Service quality, customer satisfaction, perceived value and brand loyalty: A critical review of the literature. Academic Journal of Interdisciplinary Studies.doi:10.5901/ajis.2013.v2n9p223

Triatmanto, B., Nirwanto, N., \& Razak, I. (2016). The impact of product quality and price on customer satisfaction with the mediator of customer value. IISTE: Journal of Marketing and Consumer Research, 30, 59-68.

Tsoukatos, E. and Rand, G.K. (2006) 'Path analysis of perceived service quality, satisfaction and loyalty in Greek insurance', Managing Service Quality, 16, 5, 501-519.

Turel, O., \& Serenko, A. (2006). Satisfaction with mobile services in Canada: An empirical investigation. Telecommunications policy, 30(5-6), 314-331.

Weerasiri, R. A. S. (2015). A Study on Service Quality and Customer Satisfaction of Supermarkets in Sri Lanka. Sri Lanka Journal of Marketing, 1(2), 36-46.

Wong, A., \& Zhou, L. (2006). Determinants and outcomes of relationship quality: A conceptual model and empirical investigation. Journal of International Consumer Marketing, 18(3), 81-105.

Zamazalová, M. (2008). Customer satisfaction. Acta Oeconomica Pragensia, 4, 76-82 


\title{
Authors' Detail
}

1. Mr. Nasrul Hakimi Bin Noor Azman currently doing his Diploma in Accounting at University of Malaya Centre for Continuing Education (UMCCed). His passion in Accounting, Business and Islamic Finance as the main interest.

\author{
Email address : nasrulhakimiazman99@gmail.com \\ HP : : $\quad$ +6012-8994650 \\ Address : University of Malaya Centre for Continuing Education, Wisma R\&D University \\ Malaya, Jalan Pantai Baharu, 59990, Kuala Lumpur.
}

2. Miss Ng Kah Xsin is currently doing her Diploma in Accounting at University of Malaya Centre for Continuing Education (UMCCed) since 2017 and her area of interests are in Banking and Finance, Accountancy and Marketing.

Email address: ngkahxsin29@gmail.com

HP: +60 10-9511 882

Address: University of Malaya. Centre for Continuing Education, Wisma R\&D Universiti Malaya, Jalan Pantai Baharu, 59990 Kuala Lumpur

3. Miss Nur Sorfina Binti Suleiman is currently doing her diploma in University Malaya and will be completing soon. Her passion towards business and finance. Besides, she plans to further her studies to higher level in business field. Though her passion is towards business and finance area, yet she loves to express her thoughts through writings. Hence, she owned a blog herself.

Email address: sselefina@gmail.com

HP: +60 1139002090

Address: University of Malaya. Centre for Continuing Education, Wisma R\&D Universiti Malaya, Jalan Pantai Baharu, 59990 Kuala Lumpur

4. Ms. Nur Iman An Nisaa Binti Nor Azman is currently doing her Diploma in Accounting at University of Malaya Centre for Continuing Education (UMCCed), and her area of interests are in Finance and Marketing.

Email address: imannessa@gmail.com

HP: +60192020987

Address: University of Malaya. Centre for Continuing Education, Wisma R\&D Universiti Malaya, Jalan Pantai Baharu, 59990 Kuala Lumpur

5. Ms. Nor Azirah Binti Ayub is currently doing her Diploma in Accounting at University of Malaya Centre for Continuing Education (UMCCed) since 2017 and her main area of interests are in Accountancy and Marketing, Banking and Finance and Community involvements.

Email address: azirah256@gmail.com

HP: +60 196105419

Address: University of Malaya. Centre for Continuing Education, Wisma R\&D Universiti Malaya, Jalan Pantai Baharu, 59990 Kuala Lumpur

6. Miss Nur Sabrina Binti Mohd Halid is currently doing her Diploma in Accounting at University of Malaya Centre for Continuing Education (UMCCed) since 2017 and her area of interests are in Economics, Accountancy and Marketing.

Email address: sabrinahalid@yahoo.com

HP: +60 122567094

Address: University of Malaya. Centre for Continuing Education, Wisma R\&D Universiti Malaya, Jalan Pantai Baharu, 59990 Kuala Lumpur 
7. Miss Nur Atiqah T.N Winda Wijaya is currently doing her Diploma in Accounting at University of Malaya Centre for Continuing Education. Her interest is in Islamic Finance and Business Management.

Email: atiqahwinda48@gmail.com

HP: 011-23270472

Address: University of Malaya Centre for Continuing Education, Wisma R\&D University of Malaya, Jalan Pantai Baharu, 59990 Kuala Lumpur

8. Miss Nur Adila Anati Binti Md Shah currently doing her Diploma in Accounting at University of Malaya Centre for Continuing Education (UMCCed) and interested in Business Finance, Economics and Marketing.

Email: Nuradila5016@gmail.com

HP: $011-23167364$

Address: University of Malaya Centre for Continuing Education, Wisma R\&D University Malaya, Jalan Pantai Baharu, 59990 Kuala Lumpur

9. Isai Amutan Krishnan is interested in the area of in human resource development \& management, business, English language teaching (ELT), and performing arts. $\mathrm{He}$ is also a freelance consultant locally and abroad.

E-mail address: amuthan.isai@gmail.com

HP: +60123845100

Address: Magic Palms School, Vientiane, Laos.

10. Mr. Vasudevan Naidu Kanan is currently a Project Manager in the Business Communication Department of O'Connor's Engineering Sdn. Bhd, Kuala Lumpur. He did his Masters in Global Business from SEGI University Kota Damansara. He used to work in CIMB Group from the department of Client Management. His research interest is in social sciences, business and information technology.

E-mail address: evanleo05@gmail.com

HP: +60129790535

Address: O'Connor's Engineering Sdn. Bhd. Bagunan O'Connor No.13 Jlaan 223, 46100 Petaling Jaya, Selangor. 